\title{
ANTERIOR DECOMPRESSION AND STABILISATION OF METASTATIC SPINAL FRACTURES
}

\author{
MALCOLM W. FIDLER
}

\author{
From the Medisch Centrum Slotervaart, Amsterdam
}

\begin{abstract}
Seventeen patients with pathological fractures of the thoracolumbar spine which had not responded to conservative treatment are reported. All had compression of the spinal cord and/or severe pain. All (except one treated by lateral rhachotomy) were treated by anterior decompression followed by stabilisation; when the lesion was below $\mathbf{T} 2$ the spine was stabilised anteriorly, and when it was higher posterior instrumentation was used. Sixteen of the 17 patients benefited from the procedure.
\end{abstract}

The majority of metastases compressing the thoracolumbar spinal cord are treated by radiotherapy, which leads to improvement in about $50 \%$ of patients (Black 1979). Until comparatively recently, laminectomy was the only operative treatment; the results were disappointing and sometimes the operation actually precipitated neurological deterioration (Wright 1963; Meijer 1977; Gilbert, Kim and Posner 1978) unless the compression was strictly posterior (Brice and McKissock 1965; Hall and Mackay 1973). These poor results are not surprising, especially if one considers that the cause of the compression usually lies anterior to the cord; anatomically, a posterior approach to such a lesion thus seems fraught with danger (Fidler and Goedhart 1984). If surgery is to have a place in the treatment of metastatic spinal lesions and pathological fractures, anterior decompression would seem the logical choice. Indeed, the anterior approach to pathological fractures has already been used successfully by Salzer et al. (1973) and Harrington (1981).

In the present series 17 patients with anterior spinal cord compression and/or severe pain caused by metastases and pathological fractures of the spine were treated by decompression and stabilisation, and their results are reported. Also described is a technique of anterior stabilisation below T2 which, by using an interbody distractor, requires minimal dissection and disturbance of surrounding tissues.

\section{PATIENTS AND METHODS}

Operation was carried out to relieve anterior spinal cord compression in one case, severe pain in three cases and anterior cord compression plus pain in 14 cases (Cases 4 and 12 refer to the same patient treated on two separate occasions 13 months apart).

M. W. Fidler, FRCS, Orthopaedic Surgeon

Onze Lieve Vrouwe Gasthuis, le Oosterparkstraat 179.

1091 HA Amsterdam, The Netherlands.

(C) 1986 British Editorial Society of Bone and Joint Surgery $0301-620 \mathrm{X} / 86 / 1001 \$ 2.00$

Every patient except one was bedridden (or virtually so) because of neurological deficit, severe pain or a combination of both. Patients were considered for operation only when conservative treatment offered no hope of local success. No patient was considered to be terminal. Operation was indicated for a pathological fracture which caused anterior spinal cord compression if the causative tumour was unresponsive to radiotherapy or if the maximum dose had already been given; if the cord was indented by a fragment of bone, radiotherapy could not be expected to be successful. Operation was also indicated if a pathological fracture was causing severe pain which was resistant to conservative therapy. An uncontrollable rapidly-growing metastasis was a contraindication to operation.

Pre-operative investigations. The clinical picture served to identify the level of compression; this was then confirmed by plain radiographs. A technetium bone scan confirmed the suspected lesion but was carried out principally to detect metastases in adjacent vertebrae and throughout the body. A lumbar myelogram (Fig. 1) was performed to determine the extent of spinal cord compression: if there was complete obstruction, a contrast

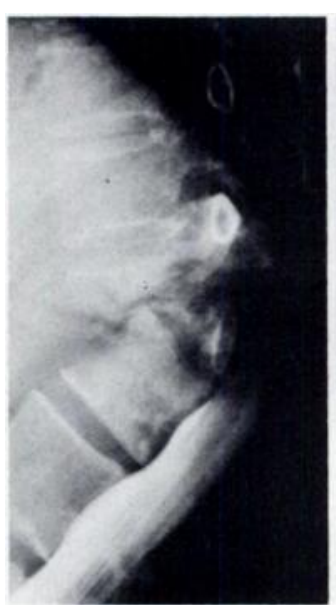

Fig. 1

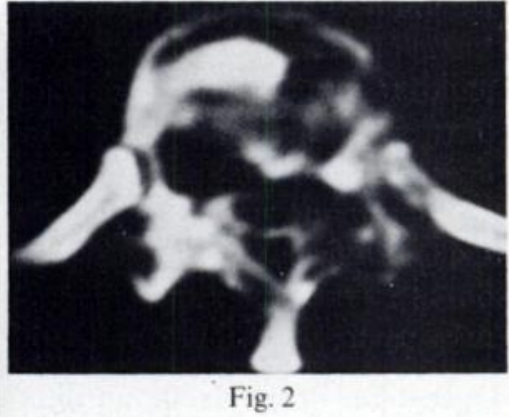

Case 16. Figure 1-A lateral myelogram revealed collapse of T10-12 with complete obstruction to the flow of contrast medium. Figure 2-A CT scan at the level of T11 performed after the myelogram shows a severely narrowed vertebral canal. The subarachnoid space is almost obliterated 


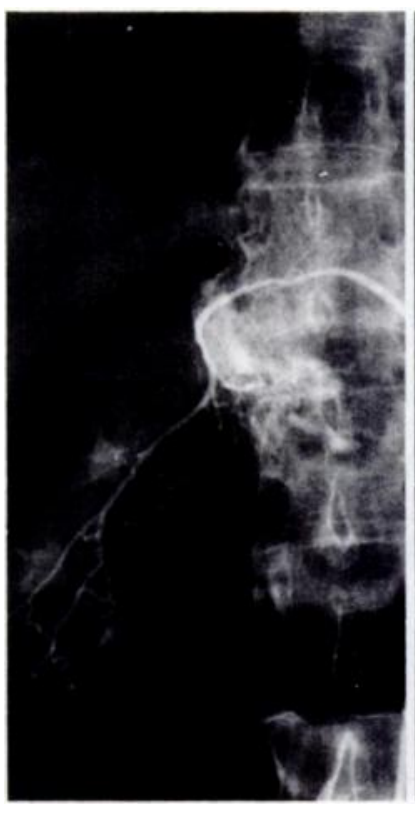

Fig. 3

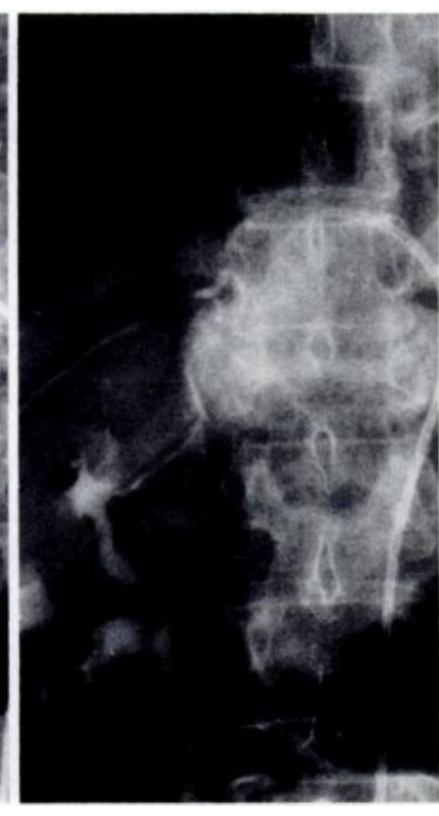

Fig. 4
Arteriograms taken before embolisation (Fig. 3) and after (Fig. 4) There is an obvious reduction in the vascularity of the affected vertebral body after embolisation.

medium was injected cervically so that the cranial extent of the compression could be seen, as well as the presence of any skip lesions. After the myelogram, a CT scan (Fig. 2) was performed to assess the extent of the vertebral destruction, the site of maximum cord compression and any associated paravertebral extension of the tumour. Tomography or sagittal reconstruction of the CT scan was viewed in combination with the CT images to complete the three-dimensional picture of the diseased region.

The blood supply of the spinal cord must be preserved during vertebral body resection (Lazorthes et al. 1971; Dommisse 1980). Selective angiography was therefore used to identify any major medullary feeder artery such as that of Adamkiewicz in the proposed operation area. Spinal metastases are often highly vascular, and any segmental artery supplying the tumour (but not giving rise to any medullary feeder artery) was embolised to reduce operative blood loss (Figs 3 and 4). Angiography and embolisation were usually carried out on the day before operation (with a longer interval there is a danger of collateral vessels opening up).

If there is any doubt as to the nature of a lesion in the vertebral body and urgent decompression is not essential, then a needle biopsy is indicated; if such a lesion is strictly posterior, then an open biopsy is probably safer.

Operation. Prophylactic antibiotics are given beginning half an hour before the operation.

Decompression. The technique for decompressing malignant compression of the thoracolumbar spinal cord is based on that used for spinal infection (Hodgson and Stock 1956, 1960; Hodgson et al. 1960; Jackson 1971; Kemp et al. 1973). The patient is placed in the lateral thoracotomy position with the affected segment of the spine over the operating table bridge, which is raised to improve access. The chest is opened on the side with greater destruction of the vertebral body and greater cord compression. If a major medullary feeder artery is present at the level of the lesion, the chest is usually entered through the opposite side. If one uses the same side, particular care is necessary to preserve the vessel, especially when operating in the region of the intervertebral foramen where the artery originates and important anastomoses occur. For the general anaesthetic a double lumen tube is used so that, if necessary, the lung can be collapsed to facilitate exposure. As it is easier to work in the chest in a caudal rather than a cranial direction, the level for the thoracotomy is chosen to provide comfortable access to the cranial end of the lesion. If the site of the intended thoracotomy is well chosen, one can reach up to T2 or down to T12. Release of the posterior margin of the diaphragm and the crus provides ready access for resection of the body of $\mathrm{Ll}$ and instrumentation to $\mathrm{L} 2$.

The proposed incision is marked on the skin with a metal marker and the level checked radiographically. During the operation further radiographic assistance is almost never necessary, but as a precaution any supports are positioned so as not to interfere with the possible use of the image-intensifier. On opening the chest, the pleural cavity is palpated and the lung is either retracted forwards or collapsed to expose the spine, where an obvious swelling will be seen, corresponding to the site of the tumour. The mediastinal pleura is incised longitudinally along the anterior margin of the affected vertebral bodies and then posteriorly across the middle of the affected segment. The flaps of this $T$-incision are elevated and held aside with stay-sutures and short Kirschner wires. The segmental vessels crossing the affected area are identified anteriorly, ligated and divided. The lateral ends of these vessels are then elevated back to the posterior margins of the vertebral bodies and then retied or clipped and cut short, special care being taken in the region of the intervertebral foramina. The space between the aorta and tumour is gently explored and any vessels entering the anterior surface of the affected vertebrae are clipped. If embolisation has been successful, the vessels will contain thrombus; as an added precaution, however, clips are applied. If embolisation was not possible, the aorta must be mobilised further so that clips can also be applied to the appropriate contralateral segmental vessels. A window is made in the middle third of the affected segment and deepened in the coronal plane to form a tunnel across the spine. The posterior wall of the tunnel is then removed. Palpation of an intervertebral foramen with a dural elevator or Watson-Cheyne dissector guides one to the plane of the vertebral canal, as does palpation along the end-plates of the intact cranial and caudal vertebrae when these are exposed. The posterior longitudinal ligament is often intact but should be removed to expose any epidural tumour. In all except one of our 


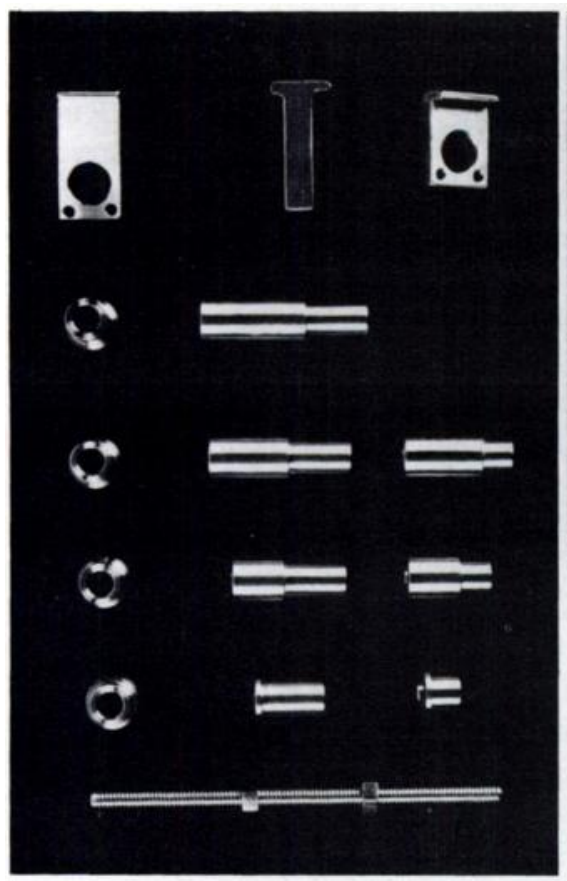

cases, it has been possible to peel the tumour completely off an intact dura. The anterior portions of the vertebral bodies are then removed until only the anterior longitudinal ligament and a periosteal shell on the far side remain. If necessary, the pedicle and the base of the transverse process can also be removed to give access to lateral and even posterolateral epidural tumour tissue. During such a manoeuvre one should be careful of the emerging nerve roots. At all stages of this operation, tissue is being withdrawn away from the dura and spinal cord under direct vision; the dura never needs to be retracted or in any way pressed upon. Having completed the dural decompression, the pleural cavity is rinsed with Dakin's solution in the hope of reducing local tumour dissemination and then rinsed with saline solution. These solutions are warmed to avoid any adverse cardiovascular effects.

In the upper thoracic spine $\mathrm{T} 1$ and $\mathrm{T} 2$ can be decompressed anteriorly by an incision along the anterior border of the sternomastoid muscle. The body of T3 can be comfortably exposed (as in Case 18) by mobilising the scapula and resecting the posterior portion of the third rib (Hodgson et al. 1960; Veraart and Eijsman, personal communication). The simultaneous anterior exposure of $\mathrm{T} 1, \mathrm{~T} 2$ and $\mathrm{T} 3$ requires a combined cervical and thoracic approach, which was considered for Case 5 but seemed inadvisable given her age (65 years) and general condition; for this patient decompression was carried out by means of lateral rhachotomy (Capener 1954).

Stabilisation. To correct any kyphosis the healthy vertebral bodies above and below the excised tumour tissue are distracted initially with a spinal spreader (such as the one devised by Morscher and made by Mathys, of Bettlach in Switzerland) and then with a central modular distractor inserted between the vertebral end-plates (Figs 5 and 6). The central threaded rod of the distractor is cut

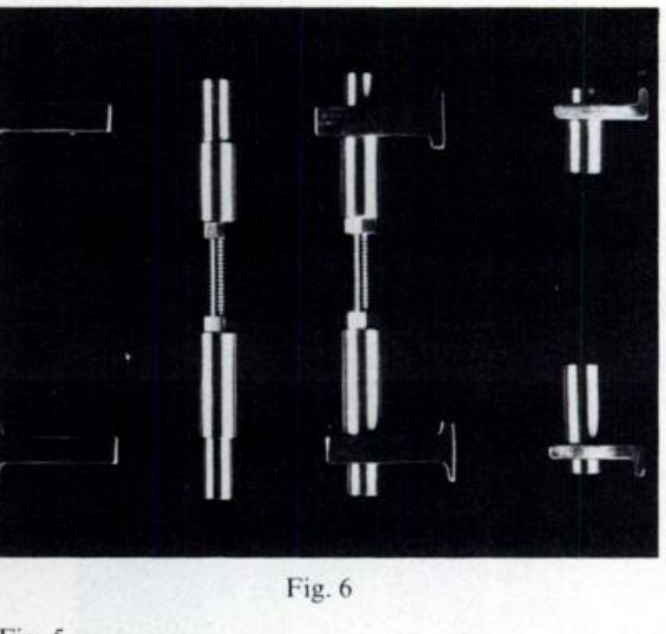

Fig. 5

Figure 5-The components of the intervertebral distractor can be assembled in the desired length by choosing the appropriate sleeves and length of the threaded rod. Longer sleeves allow more distraction. Smaller hooks and sleeves (right) are more suitable for smaller vertebrae. All components are interchangeable. Figure 6The assembled threaded inter-body distractor.

to length and so centred that the lips of the hooks fit around the anterior edges of the end-plates deep to the anterior longitudinal ligament. The hooks are then separated until the ligament is taut. Anti-rotation pits for the cement are then cut in the exposed vertebral endplates with a power burr. The dura is protected by a $5 \mathrm{~mm}$ layer of Gelfoam while low-viscosity methylmethacrylate cement is poured into the defect. During polymerisation the area is doused in cold saline. At this stage, while the cement is still soft, the operating table bridge is flattened, the rib spreader removed and the ribs temporarily approximated, for otherwise the cement sets with an in-built scoliosis and the obliquely separated ribs would rotate the cranial vertebral body away from the side of the incision. Such an effect is shown by lateral angulation and translation of the vertebral bodies on the postoperative anteroposterior radiograph. This occurred early in the series but, although it did not give rise to any adverse effects, it should be avoided. At the end of the operation the mediastinal pleura is loosely approximated and the intercostal nerves above and below the incision are injected with $0.5 \%$ bupivacaine hydrochloride in order to reduce postoperative pain. The chest is then closed routinely with an underwater drain which can usually be removed at 24 to 48 hours; the patient is subsequently mobilised as well as the pre-existing neurological lesion permits.

This technique is applicable for vertebral bodies T3 to $\mathrm{T} 11$ inclusive, where the method of stabilisation resists compression, and where rotation and extension are effectively controlled by the rib cage. When stabilising T12 or L1, added support is considered necessary. Initially staples from vertebral body to cement were used; no problems were encountered, but for even greater security a method was developed combining a thick-threaded Harrington rod and two modified Zielke screws used to 


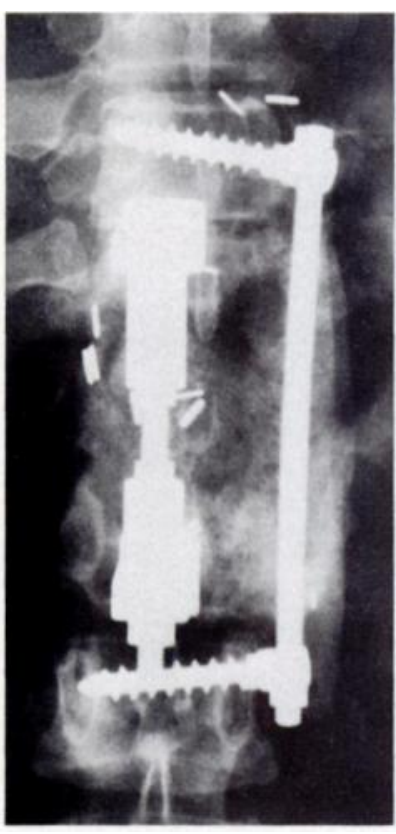

Fig. 7

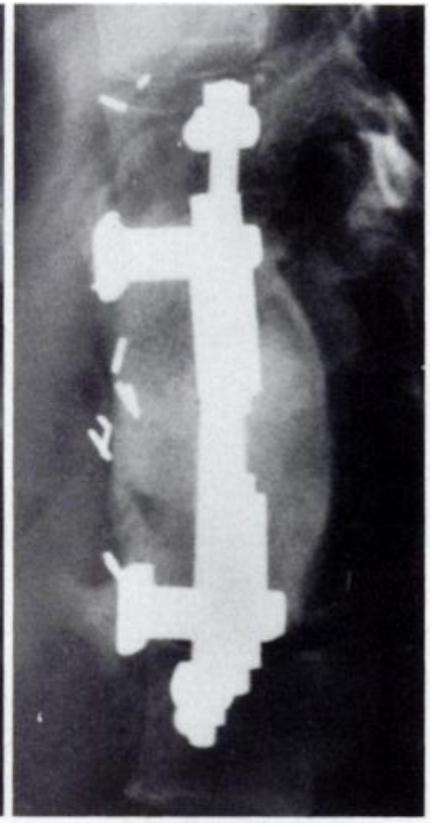

Fig. 8
Postoperative result. Anteroposterior radiograph (Fig. 7) and lateral radiograph (Fig. 8) show that, at the thoracolumbar junction, stabilisation has been achieved with the interbody distractor and cement, augmented with a strengthened and modified Zielke system (same patient as Figs 1 and 2)

provide compression; this appears to be effective (Figs 7 and 8). The modified Zielke device is inserted before the cement is added. Because of limited anterior access and the small size of the upper two thoracic vertebrae, they are stabilised by posterior segmental instrumentation with laminar wires (Luque 1982) and cement.

Ancillary treatment. Any postoperative radiotherapy is given when wound healing is satisfactory, though never before the fifth day. Chemotherapy is usually given in one form or another until the various possibilities are exhausted; it is, however, not begun until two weeks after the operation because of possible deleterious effects on wound healing and also because adverse haematological consequences may impair the patient's postoperative resistance to infection.

\section{RESULTS}

Neurological function was assessed by using the classification suggested by Frankel et al. (1969) but with the addition of a subgroup $4 \mathrm{~S}$ (Table I). The pre-operative scores and those at the time of maximal recovery, as well as other details for all 17 patients, are shown in Table II. There was neurological improvement in 14 of the 15 patients who presented with a deficit; the exception (Case 12) died from adult respiratory distress syndrome without regaining consciousness.

Pain was considerably or totally relieved in all patients except Case 12.

The stabilisation techniques proved effective in every case, although there was some postoperative wedging of $\mathrm{T} 7$ in Case 14; this has remained unchanged. In

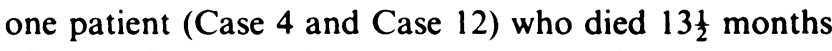
after the first operation and two weeks after her second operation, and in a second patient (Case 15) postmortem examination of the instrumented spines revealed good fixation. Posterior fusion was added in three patients: in Case 1, where the prognosis of the patient's solitary myeloma was good (Valderrama and.Bullough 1968) and our anterior approach was as yet untested; in Case 11, before the use of the modified Zielke system; and in Case 16 as a safety precaution in a patient who was returning abroad. During the first two fusions no movement of the relevant spinous processes could be elicited; in the third patient slight movement was possible.

Supplementary details for some of the patients follow.

Case 7. After $6 \frac{1}{2}$ months this patient was again confined to bed by painful metastases at other levels (L3 and L4).

Case 8. Four days before the anterior operation, a laminectomy had been carried out in the neurosurgical department. To provide temporary stabilisation before anterior decompression and stabilisation, it was necessary to add a Harrington rod and laminar wires at T9L3. There was local recurrence, causing pain in the flank after 17 months. However, there is still no evidence, either clinical or tomographic, of dural compression.

Case 10. The patient developed painful pelvic metastases after nine months and was confined to bed, although cord function remained intact.

Case 15. Postoperatively this patient made satisfactory progress with almost complete neurological recovery. But 11 days after operation, she suddenly developed a rapidly progressive tetraplegia. She refused further investigation and treatment and died five days later. The preoperative cervical and lumbar myelograms had revealed no evidence of spinal cord compression other than that at T12.

Case 18. After two weeks, this patient developed a paraplegia due to epidural metastasis at T2. The lesion was confirmed using a CT scan before and after intravenous contrast enhancement. A second decompression was not thought to be in the patient's interest.

Table I. Neurological assessment score derived from Frankel et al. (1969)

\begin{tabular}{ll}
\hline Finding & Score \\
\hline Complete lesion & 1 \\
Only sensation present & 2 \\
Motor power present, but of no practical use & 3 \\
Motor function present and sufficient for walking & 4
\end{tabular}

Motor function present but with sphincter disturbance 4S

No neurological symptoms but minimal signs (for example, 5 brisk reflexes)

Improved condition but insufficient to include in the next + groups

* Walking may be prevented by non-neurological factors, for example, pain or metastases at other sites 
Table II. Details of 17 patients ( 18 cases $) \dagger$

\begin{tabular}{|c|c|c|c|c|c|c|c|c|c|c|c|c|c|}
\hline \multirow[b]{2}{*}{ Case } & \multirow[b]{2}{*}{ Age } & \multirow[b]{2}{*}{ Sex } & \multirow[b]{2}{*}{ Primary } & \multirow[b]{2}{*}{$\begin{array}{l}\text { Results of } \\
\text { myelogram }\end{array}$} & \multirow[b]{2}{*}{ Symptoms } & \multicolumn{3}{|l|}{ Operation } & \multirow{2}{*}{$\begin{array}{l}\text { Radio- } \\
\text { therapy } \\
\text { (rads) }\end{array}$} & \multirow[b]{2}{*}{$\begin{array}{l}\text { Postoperative } \\
\text { results }\end{array}$} & \multirow{2}{*}{$\begin{array}{l}\text { Survival } \\
\text { in months } \\
\text { (ambulant) }\end{array}$} & \multicolumn{2}{|c|}{ Frankel score } \\
\hline & & & & & & $\begin{array}{l}\text { Decom- } \\
\text { pression }\end{array}$ & $\begin{array}{l}\text { Metal }+ \\
\text { cement }\end{array}$ & Graft & & & & $\begin{array}{l}\text { Pre- } \\
\text { operative }\end{array}$ & $\begin{array}{l}\text { Post- } \\
\text { operative }\end{array}$ \\
\hline 1 & 58 & $\mathbf{M}$ & Myeloma & $\begin{array}{l}\text { T8, } \\
\text { almost } \\
\text { complete } \\
\text { block }\end{array}$ & $\begin{array}{l}\text { Pain, } \\
\text { retention } \\
\text { of urine }\end{array}$ & $\begin{array}{l}\text { Anterior } \\
\text { T8 }\end{array}$ & $\begin{array}{l}\text { Anterior } \\
\text { T7-9 }\end{array}$ & $\begin{array}{l}\text { Posterior } \\
\text { T } 7-9\end{array}$ & $\begin{array}{l}\text { Postop. } \\
4000\end{array}$ & $\begin{array}{l}\text { Ambulant at } 10 \\
\text { days, } \\
\text { micturition } \\
\text { normal }\end{array}$ & $\begin{array}{c}42^{*} \\
(42)\end{array}$ & $4 S$ & 5 \\
\hline 2 & 46 & $\mathrm{~F}$ & Breast & $\begin{array}{l}\text { T9-10 } \\
50 \% \text { block }\end{array}$ & $\begin{array}{l}\text { Pain, } \\
\text { weakness } \\
\text { (bedridden) }\end{array}$ & $\begin{array}{l}\text { Anterior } \\
\text { T9-10 }\end{array}$ & $\begin{array}{l}\text { Anterior } \\
\text { T8-11 }\end{array}$ & & Pre-op. & $\begin{array}{l}\text { Sitting only, } \\
\text { due to multiple } \\
\text { metastases }\end{array}$ & $\begin{array}{r}21 \\
(0)\end{array}$ & 4 & $4+$ \\
\hline 3 & 54 & $\mathbf{M}$ & Kidney & $\begin{array}{l}\text { T12-L1, } \\
\text { partial } \\
\text { block }\end{array}$ & $\begin{array}{l}\text { Pain } \\
\text { (bedridden) }\end{array}$ & $\begin{array}{l}\text { Anterior } \\
\text { T12-L1 }\end{array}$ & $\begin{array}{l}\text { Anterior } \\
\text { T11-L2 }\end{array}$ & & $\begin{array}{l}\text { Pre-op. } \\
3100\end{array}$ & $\begin{array}{l}\text { Ambulant at } 5 \\
\text { days }\end{array}$ & $\begin{array}{l}3 \\
\text { (3) }\end{array}$ & 5 & 5 \\
\hline 4 & 56 & $\mathbf{F}$ & Breast & $\begin{array}{l}\text { T6, partial } \\
\text { block }\end{array}$ & $\begin{array}{l}\text { Progressive } \\
\text { weakness, } \\
\text { numbness, } \\
\text { retention } \\
\text { of urine, } \\
\text { pain }\end{array}$ & $\begin{array}{l}\text { Anterior } \\
\text { T6 }\end{array}$ & $\begin{array}{l}\text { Anterior } \\
\text { T5-7 }\end{array}$ & & $\begin{array}{l}\text { Pre-op. } \\
4200\end{array}$ & $\begin{array}{l}\text { Ambulant at } 3 \\
\text { days. } \\
\text { micturition } \\
\text { normal }\end{array}$ & $\begin{array}{l}13 \frac{1}{2} \\
(13)\end{array}$ & 3 & 5 \\
\hline 5 & 66 & $\mathbf{F}$ & $\begin{array}{l}\text { Lung, } \\
\text { alveolar } \\
\text { cell }\end{array}$ & $\begin{array}{l}\text { T1-3, } \\
\text { complete } \\
\text { block }\end{array}$ & $\begin{array}{l}\text { Pain, } \\
\text { progressive } \\
\text { weakness, } \\
\text { numbness }\end{array}$ & $\begin{array}{l}\text { Left lateral } \\
\text { rhachotomy, } \\
\mathrm{Tl}-3 \\
\text { (see text) }\end{array}$ & $\begin{array}{l}\text { Posterior } \\
\text { C4-T7 }\end{array}$ & & $\begin{array}{l}\text { Pre-op. } \\
3000\end{array}$ & Sitting & $\begin{array}{l}\text { [died of } \\
\text { myocardial } \\
\text { ischaemia] } \\
(0)\end{array}$ & 3 & $3+$ \\
\hline 6 & 61 & $\mathbf{M}$ & $\begin{array}{l}\text { Lung } \\
\text { (squamous) }\end{array}$ & $\begin{array}{l}\text { T9-11 } \\
\text { complete, } \\
\text { block }\end{array}$ & $\begin{array}{l}\text { Pain, } \\
\text { paraparesis }\end{array}$ & $\begin{array}{l}\text { Anterior } \\
\text { T9-11 }\end{array}$ & $\begin{array}{l}\text { Anterior } \\
\text { T8-12 }\end{array}$ & & $\begin{array}{l}\text { Pre-op. } \\
5000\end{array}$ & $\begin{array}{l}\text { Neurological } \\
\text { function } \\
\text { increased, then } \\
\text { declined: } \\
\text { recurrence of } \\
\text { cerebral } \\
\text { metastases }\end{array}$ & $\begin{array}{l}2 \\
(0)\end{array}$ & 3 & $3+$ \\
\hline 7 & 38 & F & Breast & $\begin{array}{l}\text { LI, } \\
\text { almost } \\
\text { complete } \\
\text { block }\end{array}$ & $\begin{array}{l}\text { Pain } \\
\text { (bedridden) }\end{array}$ & $\begin{array}{l}\text { Anterior } \\
\text { L1 }\end{array}$ & $\begin{array}{l}\text { Anterior } \\
\text { T12-L2 }\end{array}$ & & $\begin{array}{l}\text { Pre-op. } \\
2100: \\
\text { postop. } \\
2100\end{array}$ & $\begin{array}{l}\text { Ambulant at } 5 \\
\text { days }\end{array}$ & $\begin{array}{l}7 \\
(6 !)\end{array}$ & 5 & 5 \\
\hline 8 & 67 & $\mathbf{M}$ & Kidney & $\begin{array}{l}\text { Ll, } \\
\text { complete } \\
\text { block }\end{array}$ & $\begin{array}{l}\text { Pain, virtually } \\
\text { paraplegic }\end{array}$ & $\begin{array}{l}\text { Anterior } \\
\text { Ll }\end{array}$ & $\begin{array}{l}\text { Anterior } \\
\text { T12-L2 }\end{array}$ & & $\begin{array}{l}\text { Postop. } \\
3000\end{array}$ & $\begin{array}{l}\text { Ambulant at } 4 \\
\text { weeks }\end{array}$ & $\begin{array}{l}18^{*} \\
(18)\end{array}$ & 3 & 5 \\
\hline 9 & 70 & $\mathbf{M}$ & $\begin{array}{l}\text { Adeno- } \\
\text { carcinoma } \\
\text { (gastro- } \\
\text { intestinal?) }\end{array}$ & $\begin{array}{l}\text { T5-7, } \\
\text { complete } \\
\text { block }\end{array}$ & $\begin{array}{l}\text { Pain, } \\
\text { virtually } \\
\text { paraplegic }\end{array}$ & $\begin{array}{l}\text { Anterior } \\
\text { T5-7 }\end{array}$ & $\begin{array}{l}\text { Anterior } \\
\text { T4-8 }\end{array}$ & & $\begin{array}{l}\text { Postop. } \\
3000\end{array}$ & $\begin{array}{l}\text { Ambulant at } 4 \\
\text { weeks }\end{array}$ & $\begin{array}{r}64 \\
(6)\end{array}$ & 3 & 4 \\
\hline 10 & 33 & $\mathbf{F}$ & $\begin{array}{l}\text { Fibro- } \\
\text { osteo- } \\
\text { sarcoma } \\
\text { (right arm) }\end{array}$ & $\begin{array}{l}\text { T11-12, } \\
\text { anterior } \\
\text { impression }\end{array}$ & $\begin{array}{l}\text { Pain, hesitancy } \\
\text { (chair/ } \\
\text { bedridden) }\end{array}$ & $\begin{array}{l}\text { Anterior } \\
\text { T11-12 }\end{array}$ & $\begin{array}{l}\text { Anterior } \\
\mathrm{T} 10-\mathrm{L} 1\end{array}$ & & $\begin{array}{l}\text { Pre-op. } \\
20 \times 200 \\
\text { postop. } \\
4000\end{array}$ & $\begin{array}{l}\text { Ambulant at } 4 \\
\text { days }\end{array}$ & $\begin{array}{l}14 \\
\text { (9) }\end{array}$ & $4 S$ & 5 \\
\hline 11 & 64 & $F$ & Breast & $\begin{array}{l}\text { T11-L1, } \\
\text { complete } \\
\text { block }\end{array}$ & $\begin{array}{l}\text { Pain, } \\
\text { progressive } \\
\text { weakness } \\
\text { (bedridden) }\end{array}$ & $\begin{array}{l}\text { Anterior } \\
\text { TII-L1 }\end{array}$ & $\begin{array}{l}\text { Anterior } \\
\text { T10-L2 }\end{array}$ & $\begin{array}{l}\text { Posterior } \\
\text { T10-L2 } \\
\text { (3 months } \\
\text { postop.) }\end{array}$ & $\begin{array}{l}\text { Pre-op. } \\
3000 \\
\text { postop. } \\
2100\end{array}$ & $\begin{array}{l}\text { Semi-ambulant } \\
\text { at I week. } \\
\text { ambulant at } 2 \\
\text { months }\end{array}$ & $(13)^{*}$ & 3 & 5 \\
\hline 12 & 57 & $F$ & Breast & $\begin{array}{l}\mathrm{T} 2 \text {, } \\
\text { complete } \\
\text { block }\end{array}$ & $\begin{array}{l}\text { Virtually } \\
\text { paraplegic }\end{array}$ & $\begin{array}{l}\text { Anterior } \\
\text { T2 }\end{array}$ & $\begin{array}{l}\text { Posterior } \\
\text { C6-T5, } \\
\text { right; } \\
\text { C6-T6, } \\
\text { left }\end{array}$ & & $\begin{array}{l}\text { Pre-op. } \\
3900\end{array}$ & $\begin{array}{l}\text { Adult } \\
\text { respiratory } \\
\text { distress } \\
\text { syndrome }\end{array}$ & $\begin{array}{l}1 \\
(0)\end{array}$ & 3 & $N / A$ \\
\hline 13 & 54 & $\mathbf{M}$ & Kidney & $\begin{array}{l}\text { T12, } \\
\text { complete } \\
\text { block }\end{array}$ & $\begin{array}{l}\text { Pain, } \\
\text { some } \\
\text { weakness } \\
\text { (bedridden) }\end{array}$ & $\begin{array}{l}\text { Anterior } \\
\mathrm{T} 12\end{array}$ & $\begin{array}{l}\text { Anterior } \\
\text { T11-L1 }\end{array}$ & & $\begin{array}{l}\text { Pre-op. } \\
5000\end{array}$ & $\begin{array}{l}\text { Ambulant at I } \\
\text { week }\end{array}$ & $\begin{array}{c}5 \\
(5)\end{array}$ & 4 & 5 \\
\hline 14 & 62 & F & Breast & $\begin{array}{l}\text { T8, } \\
\text { almost } \\
\text { complete } \\
\text { block }\end{array}$ & $\begin{array}{l}\text { Pain. } \\
\text { weakness }\end{array}$ & $\begin{array}{l}\text { Anterior } \\
\text { T8 }\end{array}$ & $\begin{array}{l}\text { Anterior } \\
\text { T7-9 }\end{array}$ & & $\begin{array}{l}\text { Pre-op. } \\
2100\end{array}$ & $\begin{array}{l}\text { Ambulant at } 2 \\
\text { days }\end{array}$ & $\begin{array}{l}10^{*} \\
(10)\end{array}$ & 4 & 5 \\
\hline 15 & 56 & F & $\begin{array}{l}\text { Uterine } \\
\text { leiomyo- } \\
\text { sarcoma }\end{array}$ & $\begin{array}{l}\mathrm{T} 12 \text {, } \\
\text { complete } \\
\text { block }\end{array}$ & $\begin{array}{l}\text { Pain, weak } \\
\text { right leg, } \\
\text { hyperalgesia }\end{array}$ & $\begin{array}{l}\text { Anterior } \\
\mathrm{T} 12\end{array}$ & $\begin{array}{l}\text { Anterior } \\
\text { T11-L1 }\end{array}$ & & $\begin{array}{l}\text { Pre-op. } \\
2100\end{array}$ & $\begin{array}{l}\text { Sensation } \\
\text { increased. } \\
\text { ambulant at } 5 \\
\text { days }\end{array}$ & (1) & $4 S$ & $\begin{array}{l}5(1) \\
\text { see text }\end{array}$ \\
\hline 16 & 33 & F & Breast & $\begin{array}{l}\text { T10-12, } \\
\text { complete } \\
\text { block }\end{array}$ & Pain & $\begin{array}{l}\text { Anterior } \\
\text { T10-12 }\end{array}$ & $\begin{array}{l}\text { Anterior } \\
\text { T9-L1 }\end{array}$ & $\begin{array}{l}\text { Posterior } \\
\text { T9-LI } \\
\text { ( } 2 \text { weeks } \\
\text { postop.) }\end{array}$ & $\begin{array}{l}\text { Pre-op. } \\
2000: \\
\text { postop. } \\
2100\end{array}$ & $\begin{array}{l}\text { Ambulant at } 4 \\
\text { days }\end{array}$ & $\begin{array}{c}4 \\
(4)\end{array}$ & 5 & 5 \\
\hline 17 & 48 & $\mathbf{M}$ & Thyroid & $\begin{array}{l}\text { T11-12, } \\
\text { complete } \\
\text { block; } \\
\text { T8, } \\
\text { anterior } \\
\text { impression }\end{array}$ & $\begin{array}{l}\text { Pain, } \\
\text { incomplete } \\
\text { paraplegia } \\
\text { (bedridden) }\end{array}$ & $\begin{array}{l}\text { Anterior } \\
\text { T11-12 }\end{array}$ & $\begin{array}{l}\text { Anterior } \\
\text { T10-L1 }\end{array}$ & & $\begin{array}{l}\text { Pre-op. } \\
4200: \\
\text { postop. } \\
900\end{array}$ & $\begin{array}{l}\text { Standing at I } \\
\text { week. (pain at } \\
\text { T8) }\end{array}$ & $\begin{array}{l}1^{*} \\
(0)\end{array}$ & 3 & 4 \\
\hline 18 & 31 & $\mathbf{M}$ & Melanoma & $\begin{array}{l}\text { T3, } \\
\text { complete } \\
\text { block }\end{array}$ & $\begin{array}{l}\text { Pain, } \\
\text { progressive } \\
\text { weakness }\end{array}$ & $\begin{array}{l}\text { Anterior } \\
\text { T3 }\end{array}$ & $\begin{array}{l}\text { Anterior } \\
\text { T2-4 }\end{array}$ & & $\begin{array}{l}\text { Pre-op. } \\
3900\end{array}$ & $\begin{array}{l}\text { Ambulant at } 4 \\
\text { days }\end{array}$ & 11 & 4 & $\begin{array}{l}5(1: \text { recur- } \\
\text { rence of } \\
\text { lesion) }\end{array}$ \\
\hline
\end{tabular}

† Case 4 and Case 12 refer to the same patient treated twice (13 months apart)

- Still alive 


\section{DISCUSSION}

The anterior approach to the thoracolumbar spine developed by Hodgson and Stock $(1956,1960)$ and Hodgson et al. (1960) has steadily increased in popularity for the treatment of anterior spinal lesions. Since this present series began Siegal et al. (1982), Johnson, Leatherman and Holt (1983), Kostuik (1983) and Harrington (1984) have added to reports of successful treatment of spinal metastases and pathological fractures previously published by Harrington (1981) and Salzer et al. (1973). Anterior decompression and stabilisation were effective in improving neurological function or relieving pain in 27 of the 33 patients these authors treated. Sixteen of the 17 patients in the present series (including the lateral rhachotomy, Case 5) can now be added to the literature. This documented success of anterior decompression correlates well with the canine experiments of Tarlov (1954) and Tarlov and Klinger (1954), which indicated that timely and effective relief of spinal cord compression-especially if slowly progressive and incompletewould be followed by neurological recovery.

The results of anterior decompression are not only superior to those of laminectomy but also better than the overall success rate of $50 \%$ if radiotherapy is the method of treatment. This is not to say that radiotherapy should be abandoned but rather that, since there is now an acceptable alternative to laminectomy, the indications for radiotherapy should be reassessed. When anterior compression is due to a bone fragment or to a slowly progressive radio-resistant tumour, radiotherapy should not be used as the primary method of treatment.

The optimal method of stabilisation has yet to be discovered. So far various anterior devices have been used, such as simple paravertebral plates or Harrington rods (Kostuik 1983; Harrington 1981, 1984) and central prostheses reinforced with rib grafts (Senning, Weber and Yasergil 1962) or cement (Polster and Brinckmann 1977). In the first two cases in the present series, a paravertebral Harrington rod and modified hooks were used. In order to reduce the amount of dissection needed for their insertion, and also to avoid a lateral paravertebral distraction which might cause an iatrogenic scoliosis, a midline intervertebral distractor was designed. This was initially based on the Harrington ratchet rod, but later a telescopic screw-thread system, simpler to insert, was developed. As the strongest load-bearing part of the vertebra in patients over the age of $\mathbf{4 0}$ years is at the periphery (Rockoff, Sweet and Bleustein 1969), the lips of the distraction hooks were designed to fit around the anterior edges of the end-plates, beneath an elevated portion of the anterior longitudinal ligament which is retained to prevent over-distraction. A central distractor was used in Case 3 and every case thereafter. A possible disadvantage of this limited dissection is that a shell of vertebral body periosteum containing tumour cells is left behind. However, the tumour has been made less bulky and, viewed optimistically, any remaining sensitive tumour cells ought to be susceptible to postoperative radiotherapy or chemotherapy. So far in this series there have been two cases of local recurrence (Cases 8 and 18), in both of whom the tumour was resistant to therapy, and in Case 18 it was also growing rapidly.

The thoracolumbar junction in the intact spine has the highest rotatory stiffness of any motion segment, but when the facets are removed this segment becomes very mobile (White and Panjabi 1978a). Tumour destruction of the vertebral body disrupts the body-pedicle-facet continuity and has much the same effect. This theoretical weakness was in some measure confirmed by the experience of Harrington (1984); two of his eight anterior stabilisations of the thoracolumbar junction failed. From the results of Harrington and those in this series, it would seem that supplementary fixation is not required above T11 where the rib cage provides a comforting measure of stability; it is probably wise, however, to provide extra support to prevent hyperextension and rotation at the thoracolumbar junction. At present the modified and strengthened Zielke system is added and a corset is worn for three months while a firm capsule forms. This has so far proved effective, but only further experience will determine if this is sufficient or whether more massive paravertebral fixation, such as described by Dunn (1984) for spinal fractures, or routine additional posterior fusion will be necessary.

Posterior instrumentation has been advocated for simultaneous reduction and stabilisation in the treatment of traumatic fractures (Luque, Cassis and RamírezWiella 1982; Bryant and Sullivan 1983) as well as in pathological fractures (Flatley, Anderson and Anast 1984). However, Flesch et al. (1977) had come to the conclusion that anterior decompression was necessary before posterior fixation. Willen et al. (1984), using CT scans to assess the effect of Harrington instrumentation in reducing unstable thoracolumbar fractures, showed that only partial reduction of the displaced fragments narrowing the spinal canal was possible. With posterior stabilisation there is always the danger that Harrington hooks will cut out or that laminar wires will break or cut through (Flatley, Anderson and Anast 1984) or cause neurological damage (Herring and Wenger 1982; Wilber et al. 1984). Furthermore, posterior stabilisation for anterior instability is an unsound concept, both theoretically (White and Panjabi 1978b) and clinically (Gertzbein, Macmichael and Tile 1982). The posterior approach should thus be avoided if at all possible. The exception is the $\mathrm{T} 1-\mathrm{T} 2$ region where the vertebral bodies are small and anterior access is restricted. Until now vertebrae at these levels have been stabilised posteriorly.

The blood supply of the spinal cord is critical. Hodgson et al. (1960) encountered no problems when any number of segmental vessels were ligated on one side. However, in tumour surgery it is desirable to embolise or ligate the segmental vessels supplying the tumour bilaterally; preliminary localisation of any important 
medullary feeder artery would seem a wise precaution.

The use of methylmethacrylate bone cement as an integral part of the construction is essential. Cement is highly effective in resisting the compression forces to which it is subjected, although it is less effective against the shear forces which occur on the cement studs in the pits in the vertebral end-plates (Walker 1977). Such studs, however, are comparable to those used in implantation of the acetabular component during total hip replacement and have so far proved effective. The central rod also resists shear forces. In order to facilitate interdigitation between cement, metal and bone, a cement of low viscosity such as Simplex is indicated (Noble and Swarts 1983). If a cement such as Allofix G is used, it should be kept refrigerated until required and then poured immediately after mixing while still fluid. The theoretical dangers of polymerising cement causing thermal damage to the cord or cardiovascular effects have been discussed previously (Fidler 1985). No such effects have been observed, although the dura is always protected by a layer of Gelfoam and the cement cooled with saline during polymerisation. The use of cement does not interfere with any subsequent radiation treatment nor is the cement affected by radiotherapy (Murray, Bruels and Lindberg 1974; Eftekhar and Thurston 1975).

When treatment was limited to radiotherapy with or without laminectomy, the prognosis was related to the histology of the primary tumour (Rubin, Mayer and Poulter 1969; Marshall and Langfitt 1977; Gilbert, Kim and Posner 1978; Black 1979; Greenberg, Kim and Posner 1980). In the present series conservative treatment had either been exhausted or was not going to be effective locally; the type of tumour thus had little bearing on the indication for operation or on the immediate results of surgical decompression. However, the nature of the tumour and its response to conservative treatment played an important part in determining the postoperative survival of the patients or whether local recurrence would develop. Without operation all the patients would have been condemned to being bedridden by pain or paraplegia and surgery was carried out to improve the quality of life. Even so, it would seem reasonable to withhold operation in the presence of an uncontrollable, rapidly progressive metastasis. The best results can be expected where cord compression is caused by a bone fragment and especially when the tumour is responsive to conservative treatment.

Conclusion. In situations where conservative treatment is not possible or is unlikely to be effective, anterior compression of the thoracolumbar spinal cord due to pathological fracture should be treated by anterior decompression. The sooner this is performed, the better the recovery. Stability can be restored by anterior instrumentation below T2 and posterior instrumentation above that level. However, a rapidly progressing, therapy-resistant tumour is a contra-indication to operation.

Ancillary treatment-radiotherapy, chemotherapy and hormones - should be included in the management scheme whenever indicated; in this respect close co-operation with the radiotherapist and oncologist is essential.

Laminectomy should be restricted to those rare cases where the site of compression is strictly posterior as shown by a CT scan, and where conservative treatment is not possible or where the nature of a posterior lesion is in doubt.

It is a pleasure to thank $\mathrm{Mr} \mathrm{A}$. van Wijngaarden for making the interbody vertebral distractor, my colleagues in the Netherlands Cancer Institute and the departments of neurology and neurosurgery for referring the majority of the patients, Miss J. van der Hert for typing the manuscript and Mr D. van Doleweerd for the photographs. I am indebted to Drs D. Batchelor and J. van Berkel for carrying out the angiograms and embolisations, often at short notice.

\section{REFERENCES}

Black P. Spinal metastasis: current status and recommended guidelines for management. Neurosurgery 1979;5:726-46.

Brice J, McKissock W. Surgical treatment of malignant extradural spinal tumours. Br Med J 1965;1:1341-4.

Bryant CE, Sullivan JA. Management of thoracic and lumbar spine fractures with Harrington distraction rods supplemented with segmental wiring. Spine 1983;8:532-7.

Capener N. The evolution of lateral rhachotomy. J Bone Joint Surg [Br] 1954;36-B: 173-9.

Dommisse GF. The arteries, arterioles, and capillaries of the spinal cord: surgical guidelines in the prevention of postoperative paraplegia. Ann R Coll Surg Engl 1980;62:369-76.

Dunn HK. Anterior stabilization of thoracolumbar injuries. Clin Orthop 1984;189: 116-24.

Eftekhar NS, Thurston CW. Effect of irradiation on acrylic cement with special reference to fixation of pathological fractures. J Biomech 1975;8:53-6.
Fidler MW. Pathological fractures of the cervical spine: palliative surgical treatment. J Bone Joint Surg [Br] 1985;67-B:352-7.

Fidler MW, Goedhart ZD. Excision of prolapse of thoracic intervertebral disc: a transthoracic technique. J Bone Joint Surg $[B r] 1984$ 66-B: 518-22.

Flatley TJ, Anderson MH, Anast GT. Spinal instability due to malignant disease: treatment by segmental spinal stabilization. $J$ Bone Joint Surg $[\mathrm{Am}]$ 1984;66-A:47-52.

Flesch JR, Leider LL, Erickson DL, Chou SN, Bradford DS. Harrington instrumentation and spine fusion for unstable fractures and fracture-dislocations of the thoracic and lumbar spine. $J$ Bone Joint Surg [Am] 1977;59-A:143-53.

Frankel HL, Hancock DO, Hyslop G, et al. The value of postural reduction in the initial management of closed injuries of the spine with paraplegia and tetraplegia. Paraplegia 1969;7:179-92.

Gertzbein SD, Macmichael D, Tile M. Harrington instrumentation as a method of fixation in fractures of the spine: a critical analysis of deficiencies. J Bone Joint Surg $[B r]$ 1982;64-B:526-9.

Gilbert RW, Kim JH, Posner JB. Epidural spinal cord compression from metastatic tumor: diagnosis and treatment. Ann Neurol 1978; $3(1): 40-51$. 
Greenberg HS, Kim JH, Posner JB. Epidural spinal cord compression from metastatic tumor: results with a new treatment protocol. Ann Neurol 1980:8:361-6.

Hall AJ, Mackay NNS. The results of laminectomy for compression of the cord or cauda equina by extradural malignant tumour. $J$ Bone Joint Surg [Br] 1973:55 B:497 505.

Harrington KD. The use of methylmethacrylate for vertebral-body replacement and anterior stabilization of pathological fracturedislocations of the spine due to metastatic malignant disease. $J$ Bone Joint Surg $[\mathrm{Am}]$ 1981:63 A:36 46.

Harrington KD. Anterior cord decompression and spinal stabilization for patients with metastatic lesions of the spine. J Neurosurg 1984; 61: 10717

Herring JA, Wenger DR. Segmental spinal instrumentation: a preliminary report of 40 consecutive cases. Spine 1982;7:285-98.

Hodgson AR, Stock FE. Anterior spinal fusion: a preliminary communication on the radical treatment of Pott's disease and Pott's paraplegia. Brit J Surg 1956:44:266 75 .

Hodgson AR, Stock FE. Anterior spine fusion for the treatment of tuberculosis of the spine: the operative findings and results of treatment in the first onc hundred cases. J Bone Joint Surg $[\mathrm{Am}]$ 1960;42 A:295 310 .

Hodgson AR, Stock FE, Fang HSY, Ong GB. Anterior spinal fusion: the operative approach and pathological findings in 412 patients with Pott's disease of the spine. Brit J Surg 1960:48: 172-8.

Jackson JW. Surgical approaches to the anterior aspect of the spinal column. Ann R Coll Surg Engl 1971:48:83 98.

Johnson JR, Leatherman KD, Holt RT. Anterior decompression of the spinal cord for neurological deficit. Spine 1983:8:396 405.

Kemp HBS, Jackson JW, Jeremiah JD, Cook J. Anterior fusion of the spine for infective lesions in adults. J Bone Joint Surg [Br] 1973; 55 $\mathrm{B}: 71534$.

Kostuik JP. Anterior spinal cord decompression for lesions of the thoracic and lumbar spine, techniques, new methods of internal fixation results. Spine 1983:8:512 31 .

Lazorthes G, Gouaze A, Zadeh JO, Santini JJ, Lazorthes Y, Burdin P. Arterial vascularization of the spinal cord: recent studies of the anastomotic substitution pathways. $J$ Neurosurg $1971 ; 35: 253-62$.

Luque ER. The anatomic basis and development of segmental spinal instrumentation. Spine 1982:7:256-9.

Luque ER, Cassis N, Ramírez-Wiella G. Segmental spinal instrumentation in the treatment of fractures of the thoracolumbar spine. Spine 1982:7:3127

Marshall LF, Langfitt TW. Combined therapy for metastatic extradural tumors of the spine. Cancer 1977;40:2067-70.

Meijer E. Compressio medullae ten gevolge van wervelmetastasen: over de vraag naar het nut van decomprimerende laminectomieën. Thesis, Catholic University of Nijmegen. Nijmegen: GJ Thieme, 1977.
Murray JA, Bruels MC, Lindberg RD. Irradiation of polymethylmethacrylate: in vitro gamma radiation effect. J Bone Joint Surg $[\mathrm{Am}]$ 1974;56-A:311-2.

Noble PC, Swarts E. Penetration of acrylic bone cements into cancellous bone. Acta Orthop Scand 1983;54:566-73.

Polster J, Brinckmann P. Ein Wirbelkörperimplantat zur Verwendung bei Palliativoperationen an der Wirbelsäule. Z Orthop 1977;115: 118-22.

Rockoff SD, Sweet E, Bleustein J. The relative contribution of trabecular and cortical bone to the strength of human lumbar vertebrae. Calcif Tissue Res 1969;3:163-75.

Rubin P, Mayer E, Poulter C. Extradural spinal cord compression by tumor. II: high daily dose experience without laminectomy. Radio$\log y$ 1969;93: 1248-60.

Salzer M, Salzer G, Denck H, Brenner H, et al. Operative Behandlung "solitärer" Metastasen der Brust- und Lendenwirbelkörper. Arch Orthop Unfallchir 1973;15:249-54.

Senning A, Weber G, Yasargil MG. Zur operativen Behandlung von Tumoren der Wirbelsäule. Schweiz Med Wschr 1962;48:1574-6.

Siegal T, Siegal T, Robin G, Lubetzki-Korn I, Fuks Z. Anterior decompression of the spine for metastatic epidural cord compression: a promising avenue of therapy? Ann Neurol 1982;11:28-34.

Tarlov IM. Spinal cord compression studies: time limits for recovery after gradual compression in dogs. Arch Neurol Psychiat 1954;71: 588-97.

Tarlov IM, Klinger H. Spinal cord compression studies: time limits for recovery after acute compression in dogs. Arch Neurol Psychiat 1954;71:271-90.

Valderrama JAF, Bullough PG. Solitary myeloma of the spine. $J$ Bone Joint Surg [Br] 1968;50-B:82-90.

Walker PS. Human joints and their artificial replacement. Springfield, Illinois, USA: Charles C. Thomas, 1977:424.

White AA, Panjabi MM. Clinical biomechanics of the spine. Philadelphia etc: JB Lippincott, 1978a:43.

White AA, Panjabi MM. Clinical biomechanics of the spine. Philadelphia etc: JB Lippincott, 1978b:395.

Wilber RG, Thompson GH, Shafier JW, Brown RH, Nash CL Jr. Postoperative neurological deficits in segmental spinal instrumentation: a study using spinal cord monitoring. J Bone Joint Surg [Am] 1984;66-A: 1178-87.

Willén J, Lindahl S, Irstam L, Nordwall A. Unstable thoracolumbar fractures: a study by $C T$ and conventional roentgenology of the reduction effect of Harrington instrumentation. Spine 1984;9: 214-9.

Wright RL. Malignant tumors in the spinal extradural space: results of surgical treatment. Ann Surg 1963;157:227-31. 